\title{
Nickelophilous plants and their significance in phytotechnologies
}

\author{
Majeti Narasimha Vara Prasad \\ Department of Plant Sciences, School of Life Sciences, University of Hyderabad, Hyderabad 500046 AP, India. Email: \\ mnvsl@uohyd.ernet.in
}

Nickeliferous soils are invaded predominantly by members of the Brassicaceae, Cyperaceae, Cunoniaceae, Caryophyllaceae, Fabaceae, Flacourtiaceae, Euphorbiaceous, Lamiaceae, Poaceae and Violaceae, and many of these plants are metal tolerant. About $300 \mathrm{Ni}$ hyperaccumulating plants been identified. These members exhibit unusual appetite for toxic metals and elemental defense. Hyperaccumulators provide protection against fungal and insect attack. Investigations suggested that Nihyperaccumulation has a protective function against fungal and bacterial pathogens in Streptanthus polygaloides and Thlaspi montanum. Significance of nickelophilous plants and their significance in phytotechnologies are discussed in this paper.

Key words: heavy metal, hyperaccumulators, nickel, phytomanagement, tolerance.

Plantas niquelófilas e sua importância em fitotecnologias: Solos ricos em Ni, niquelíeros, são invadidos predominantemente por membros de Brassicaceae, Cyperaceae, Cunoniaceae, Caryophyllaceae, Fabaceae, Flacourtiaceae, Euphorbiaceous, Lamiaceae, Poaceae e Violaceae, e muitas dessas plantas são tolerantes e metais. Aproximadamente 300 plantas que superacumulam Ni (hiperacumuladoras) já foram identificadas. Estas plantas apresentam capacidade não usual de acumular metais tóxicos e defesa contra eles. $\mathrm{O}$ acúmulo excessivo de metais fornece proteção contra o ataque de insetos e fungos. Investigações sugerem que a hiperacumulação de Ni tem como função a proteção contra fungos e bactérias patogênicos em Streptanthus polygaloides e Thlaspi montanum. A importância de plantas niquelíferas e a sua significância em fitotecnologias são discutidas nesta revisão.

Palavras-chave: fitomanejo, metal pesado, níquel, plantas hiperacumuladoras, tolerância.

\section{INTRODUCTION}

Serpentine soils, "hotspots" of metallophyte endemics are a rich source of toxic trace elements. Serpentinized rocks are distributed all over the world viz., western north America; Newfoundland, Mount Albert in eastern Canada; Lizard peninsula, Wales and Scotland; north-east Cuba; Portugal; Italy; Balkan peninsula; Turkey; topical far east; Central Brazil; New Caledonia; south east Asia; Philippines; Japan; Zimbabwe; eastern Transvaal Loweveld of South Africa, New Zealand; greenstone belts of western Australia. (Proctor and Woodell, 1975; Sequeira et al., 1991).

Serpentine soils contain heavy metals including nickel (averaging $10 \mathrm{mg}$ per gram soil), cobalt and chromium, both of the latter being present at lower levels than nickel. Serpentine soils are also characterized by high concentrations of iron and magnesium and low nutrient levels. An interesting ecosystem is established in these biotopes driven by a nickel cycle, in which hyperaccumulating trees extract nickel from deep soil and rock layers and subsequently store it in their leaves (up to $1 \% \mathrm{Ni}$ in leaf dry matter). When the leaves are shed from the trees, the nickel is leached out into the surrounding topsoil. The solubilized metal exerts a localized selective pressure on the topsoil microflora, which acquire resistance to high levels of nickel $(>20 \mathrm{mM})$, as well as on other plant species, which are susceptible to toxic levels of Ni. Interestingly, the microflora which was not found directly beneath the canopy but in the same soil, showed tolerance to lower levels of nickel ( $3 \mathrm{mM})$ compared to the resistant population. Thus, the nickel selection pressure exists as a gradient around the hyperaccumulator plants and has a 
dramatic effect on the composition of the local microbial population (Prasad, 2001).

Hyperaccumulator plants are geographically distributed and are found throughout the plant kingdom (Brooks, 1998; Chaney et al., 1995). To date approximately 450 taxa, ranging in growth habit from annual herbs to perennials are known. Hyperaccumulator plants have been identified on all continents, both in temperate and tropical environments (table 1). Natural occurrences of hyperaccumulators for $\mathrm{Ni}$ include New Caledonia, Cuba, Southeast Asia, Brazil, southern Europe and Asia Minor; for $\mathrm{Zn}$ and $\mathrm{Pb}$ include northwest Europe; and for $\mathrm{Cu}$ and $\mathrm{Co}$ include south-central Africa. Some families and genera are particularly well documented as Ni hyperaccumulators [Brassicaceae (Alyssum and Thlaspi), Euphorbiaceae (Phyllanthus, Leucocroton) and Asterceae, $\mathrm{Zn}$ Brassicaceae (Thlaspi), and $\mathrm{Cu}$ and $\mathrm{Co}$ (Lamiaceae, Scrophulariaceae) (Brooks, 1998). There are not many $\mathrm{Cr}$ hyperaccumulators in nature, but there are numerous $\mathrm{Ni}$ hyperaccumulators. A few $\mathrm{Cr}$ hyperaccumulators have been identified, partly because $\mathrm{Cr}$ exists predominantly in the $3^{+}$ oxidation state and is very insoluble and much less available for plant uptake.

Some metals may interact competitively for accumulation (e.g., $\mathrm{Zn}$ and $\mathrm{Ni}$ in calamine and serpentine soils). The number of $\mathrm{Ni}$ hyperaccumulator taxa are more than 300 in 35 families (table 1). They commonly have 3-4 \% Ni in the dry matter of leaves. Alyssum betolonii, which is endemic to serpentine soils, is known for its high concentration of $\mathrm{Ni}(>$ $10,000 \mathrm{mg} \cdot \mathrm{kg}^{-1}$ in leaves). The fact that serpentine (ultramafic) soils also contain other elements such as $\mathrm{Cr}$ has led to the assumption that the preferential accumulation of $\mathrm{Ni}$ in many species of Alyssum is due to a selective uptake mechanism. Brassica juncea (Indian mustard) - a high-biomass producing plant that can accumulate $\mathrm{Pb}, \mathrm{Cr}(\mathrm{VI}), \mathrm{Cd}, \mathrm{Cu}, \mathrm{Ni}, \mathrm{Zn}, 90 \mathrm{Sr}$, B, and Se (Palmer et al., 2001; Prasad, 2001) produces biomass of over 20 times that of Thlaspi caerulescens (Salt et al., 1998). Brassica juncea had the best ability to transport lead to the shoots. Except for sunflower (Helianthus annuus) and tobacco (Nicotiana tabacum), other non-Brassica plants had phytoextraction coefficients less than one. B. juncea cultivars varied widely in their ability to accumulate $\mathrm{Pb}$, with different cultivars ranging from $0.04 \%$ to $3.5 \% \mathrm{~Pb}$ accumulation in the shoots and 7 to $19 \%$ in the roots (Kumar et al., 1995).

\section{Nickel hyperaccumulators - environmental implications}

One of the most persuasive ecological explanations for hyperaccumulation of $\mathrm{Ni}$ and other toxic metals appears to be the defensive role against herbivores or pathogens (Dudley, 1986; Boyd and Martens, 1988, 1994). This function, which might be similar in other hyperaccumulators, can be improved if the metal is localized in the outer layers of leaves and roots. Like in other Ni accumulators, such as Hybantus floribundus, Senecio coronatus and Thlaspi montanum variety siskiyouense, and $A$. bertolonii, $\mathrm{Ni}$ has been evidenced in leaf epidermal cells as a red-stained nickel-dimethylglyoxime complex (Boyd, 1988; Farago et al., 1988; MesjaszPrzybylowicz et al., 1994; Heath et al., 1997; Sanita Di Toppi, 2001). Furthermore, microprobe analysis has shown that leaf hairs have the highest nickel concentrations (Vergano, 1967). Similarly, in A. lesbiacum, using a micro-PIXE technique, $\mathrm{Ni}$ was found in the epidermis and in leaf trichomes (Gabrielle et al., 1997). The Ni hyperaccumulator T. montanum var. siskiyouense accumulates the highest $\mathrm{Ni}$ concentration at the leaf surface, particularly in the subsidiary cells surrounding the guard cells, and in other elongate epidermal cells, a characteristic that supports the defense hypothesis (Heath et al., 1997; Pollard and Baker, 1997).

Peterson et al. (2003) studied plants, soil, and invertebrates from Portuguese serpentine outcrops whose vegetation is dominated by the $\mathrm{Ni}$ hyperaccumulator Alyssum pintodasilvae. Peterson et al. (2003) concluded that grasshoppers, spiders, and other invertebrates that fed on these hyperaccumulators spread metals through food chain

Hyperaccumulation of metals is known for about 450 species of flowering plants, which take up, transport and sequester metallic elements, achieving tissue concentrations that are toxic to most organisms (Baker et al., 2000; Reeves and Baker, 2000). Several hypotheses have been advanced to explain the evolution of this trait (Boyd and Martens, 1992), with most attention focused on the hypothesis that hyperaccumulated metals may act as defenses against herbivory (Boyd, 1998; Boyd and Martens, 1998; Pollard, 2000; Pollard et al., 2000). With the exception of recent work by Wall and Boyd (2002), most studies to date have considered interactions between individual plants and herbivores, with little attention being paid to the effects of hyperaccumulators on their communities or ecosystems.

The broader environmental consequences of hyperaccumulation are of practical importance because of developing technologies that would use metal-accumulating plants to cleanse contaminated soil, termed phytoremediation (Schwitzguébel et al., 2002). A relatively unexplored risk of these techniques is that metals sequestered in plant tissues could be consumed by herbivores and thus mobilized into 
Table 1. Brassicaceae that accumulate nickel (Ni) (for details refer to Palmer et al., 2001).

\begin{tabular}{|c|c|c|}
\hline Metal (mg.g ${ }^{-1}$ d.wt.) & Taxa & Distribution \\
\hline 1050 & Cardamine resedifolia $\mathrm{L}$. & Italy \\
\hline $\begin{array}{l}1280 \\
2000\end{array}$ & $\begin{array}{l}\text { Alyssum singarense Boiss. and Hausskn. } \\
\text { Thlaspi bulbosum Spruner ex Boiss. }\end{array}$ & $\begin{array}{l}\text { Iraq́ } \\
\text { Greece }\end{array}$ \\
\hline 2440 & T. japonicum H.Boissieu & Japan \\
\hline 3000 & T. epirotum Halacsy & Greece \\
\hline 3140 & Pseudosempervivum sempervium Boiss and Balansa) Pobed & Turkey \\
\hline 3420 & Alyssum tenium Halacsy & Greece \\
\hline 3960 & A. fallacinum Hausskn & Crete \\
\hline 4000 & Thlaspi ochroleucum Boiss. and Heldr. & Greece \\
\hline 4480 & Alyssum alpestre $\mathrm{L}$ & Southern Europe \\
\hline 4550 & A. euboeum Halacsy & Greece \\
\hline 4590 & A. obovatum (C.A.Mey) Turez & Russia \\
\hline 4900 & A. condensatum Boiss. and Hausskn. & Iraq, Syria \\
\hline 5530 & Thlaspi montanum L. var. montanum & USA \\
\hline 6230 & Alyssum virgatum Nyar. & Turkey \\
\hline 6600 & A. smolikanum Nyar. & Greece \\
\hline 7080 & A. murale WealdstandKit & Balkans \\
\hline 7290 & A. oxycarpum Boiss. And Balansa & Turkey \\
\hline 7390 & A. giosnanum Nyar. & Turkey \\
\hline 7600 & A. peltarioides subsp.virgatiforme Nyar.T.R.Dudley) & Turkey \\
\hline 7700 & A. floribundum Boiss. and Balansa & Turkey \\
\hline 7860 & A. penjwinensis T.R.Dudley & Iraq \\
\hline 8170 & A. anatolicum Nyar. & Turkey \\
\hline 9090 & A. akamasicum B.L.Burtt & Cyprus \\
\hline 10000 & A. serpylifolium Desf & Spain \\
\hline 10200 & A. bertolonii subsp. scutarinum Nyar & Balkans \\
\hline 10200 & A. syriacum Nyar. & Syria \\
\hline 10400 & A. crenulatum Boiss & Turkey \\
\hline 10900 & A. callichroum Boiss. And Balansa & Turkey \\
\hline 11400 & Bornmulleria sp petri Greuter, Charpipn and Dittrich & Greece \\
\hline 11500 & Alyssum eriophyllum, Boiss. and Hausskn. & Turkey \\
\hline 11700 & A. discolor T.R.Dudley and Huber-Morath & Turkey \\
\hline 11800 & Thlaspi tymphaeum Hausskn. & Greece \\
\hline 11900 & Alyssum trapeziforme Nyar. & Trukey \\
\hline 12000 & Thlaspi goesingense Halacsy & Greece \\
\hline 12400 & T. graecum Jord & Greece \\
\hline 12500 & Alyssum heldreichii Hausskn. & Greece \\
\hline 12500 & A. robertianum Bernard ex Godronand Gren & Corsica \\
\hline 13400 & A. bertolonii Desv. & Italy \\
\hline 13500 & A. cilicium Boiss. And Balansa & Turkey \\
\hline 13500 & A. corsicum Duby & Corsica \\
\hline 13500 & A. huber-morathii T.R.Dudley & Turkey \\
\hline 13600 & Thlaspi kovatsii Heuffel & Yugoslavia \\
\hline 13700 & Alyssum markgrafii O.E.Schulz & Albania \\
\hline 14800 & Streptanthus polygaloides A.Gray & USA \\
\hline 16200 & Thlaspi caerulescens J.Presl & Greece \\
\hline 16300 & Alyssum chondrogynum B.L.Burtt & Cyprus \\
\hline 16500 & A. dubertretii gomb & Turkey \\
\hline 16500 & A. carcium T.R.Dudleyand Huber-Morath & Turkey \\
\hline 17100 & A. troodii Boiss. & Turkey \\
\hline 17600 & Pseudosempervium aucheri (Boiss.) Pobed & Turkey \\
\hline 18100 & Alyssum constellatum Boiss. & Turkey \\
\hline 18300 & Thlaspi rotundifolium (L.) Gaudin var. corymbosum (Gay) & Central Europe \\
\hline 18900 & Alyssum samariferum Boiss. and Hausskn. & Samar \\
\hline 18900 & Peltaria dumulosa Post & Asia \\
\hline 19200 & Bornmuellaria glabrescens (Boiss and Balansa) Cullen and TR Dudley & Turkey \\
\hline 19600 & Alyssum davisianum T.R. Dudley & Turkey \\
\hline 20000 & Alyssum cassium Boiss & Turkey \\
\hline 20800 & Thlaspi elegans Boiss & Turkey \\
\hline 18300 & T. rotundifolium (L.) Gaudin var.corymbosum (Gay) & Central Europe \\
\hline 18900 & A. samariferum Boiss. and Hausskn & Samar \\
\hline 21100 & A. pinifolium (Nyar.)T.R.Dudley & Turkey \\
\hline 21300 & Bornmuellera baldaccii (Degen) Heywood & Greece \\
\hline 22200 & Alyssum pterocarpum T.R Dudley & Turkey \\
\hline 22400 & A. lesbiacum (P.candargy) Rech.f & Greece \\
\hline 23600 & A. cypricum Nyar & Cyprus \\
\hline 24300 & A. masmenaeum Boiss & Turkey \\
\hline 26900 & Thlaspi jaubertii Hedge & Turkey \\
\hline 27300 & T. caerulescens & Germany/Belgium \\
\hline 29400 & Alyssum argenteum All & Italy \\
\hline 31000 & Thlaspi sylvium (as T. alpinum subsp. sylvium) & Central Europe \\
\hline 31200 & Bornmuellaria tymphea (Hausskn.) Hausskn & Greece \\
\hline 34400 & Peltaria emarginata (Boiss.) Hausskn. & Greece \\
\hline 35600 & Thlaspi oxyceras (Boiss.) Hedge & Turkey, Syria \\
\hline 52120 & Thlaspi cypricum Bornm. & Cyprus \\
\hline
\end{tabular}


food chains (Chaney et al., 2000). One way to investigate the possibility of such mobilization is through studies of natural ecosystems whose vegetation is dominated by hyperaccumulating plants.

High Ni concentrations in both grasshoppers and spiders suggest that the presence of hyperaccumulating plants affects the flux of $\mathrm{Ni}$ to both herbivore and carnivore trophic levels. This parallels findings recently published by Boyd and Wall (2001) showing that $\mathrm{Ni}$ accumulated by a herbivore feeding on hyperaccumulating plants can be passed on to carnivores. In one case, Boyd and Wall (2001) reported the $\mathrm{Ni}$ concentration in wild-caught crab spiders (Misumena vatia, Araneae: Thomisidae) from Streptanthus polygaloides growing on California serpentines.

The consequences and ecological role of metal hyperaccumulation is expanding rapidly. Hyperaccumulation is known for aluminium, copper, cobalt, manganesium, $\mathrm{Ni}$ and zinc (Baker and Brooks, 1989). Caledonia, Sebertia acuminata, (a tree Sapotaceae) is the classic example capable of concentrating Ni up to $26 \%$ (on a dry matter basis) in the xylem tissue. In Portuguese serpentine ecosystems, Alyssum serpyllifolium, a dominant weed, accumulates up to $10,000 \mathrm{ppm}$ of $\mathrm{Ni}$ in the leaves. The objective of this paper is to highlight the scope and limitations of Ni tolerant plants and $\mathrm{Ni}$ accumulators and their role in promoting phytotechnologies for the environmental cleanup of heavy metals and radionuclides. The below and above-ground biodiversity of Ni tolerant plants/Ni accumulators (alien/indigenous) of metalliferous substrates, is becoming increasingly considered for the phytomanagement of metal contaminated and polluted ecosystems. The Ni tolerant plants/Ni accumulators that accumulate and/or exclude metals have tremendous potential for moving phytoremediation forward. Therefore, for phytomanagement metal-accumulating plants are seeded or transplanted into metal-polluted soil/water. If metal availability were not adequate for sufficient plant uptake, the substrate would require amendment to release or arrest the mobility of metals in the substrate. Synthetic cross-linked polyacrylates (hydrogels) have protected plant roots from heavy metal toxicity and prevented the entry of toxic metals into roots. After sufficient plant growth and metal accumulation, the above-ground portions of the plant are harvested and removed, resulting in the permanent removal of metals from the site. The retention of metals by soil organic matter is also weaker at low $\mathrm{pH}$, resulting in more available metal in the soil solution for root absorption. It is suggested that the phytoextraction process is enhanced when metal availability to plant roots is facilitated through the addition of acidifying agents to the soil. Several researchers have screened fastgrowing, high-biomass producing plants (e.g. Poaceae) for their ability to tolerate and accumulate metals in their shoots. The solubilized metal exerts a localized selective pressure on the topsoil microflora, which acquire resistance to high levels (e.g. Ni $>20 \mathrm{mM}$ ). Thus, knowledge of how plants can specifically accumulate or exclude essential elements and toxic metals, particularly of Ni tolerant plants or $\mathrm{Ni}$ accumulators, is fundamental for selecting species that can be utilized for phytomanagement. This includes knowledge on bioavailability of metals in rhizospheric processes as well as translocation and processing/storage in the above-ground parts of the plant.

\section{Nickelophilous plants phytotechnologies - advantages and limitations}

The importance of below and above ground biodiversity is increasingly considered for the phytomanagement of the metalliferous ecosystems. This subject is emerging as a cutting edge area of research and gaining considerable commercial significance in the contemporary field of environmental biotechnology. Globally, metal pollution has increased several thousand-fold (Adriano, 2001). Several microbes, including mycorrhizal and non-mycorrhizal fungi, agricultural and vegetable crops, ornamentals, and wild metal hyperaccumulators and excluders are being tested both under lab and field conditions for cleanup of the metalliferous substrates in the environment. Brassicaceae has the largest number of taxa viz. 11 genera and 87 species. Different genera of Brassicaceae are known to accumulate metals. Ni hyperaccumulation is reported in 7 genera and 72 species, and $\mathrm{Zn}$ in 3 genera and 20 species. Thlaspi species are known to hyperaccumulate more than one metal i.e T.caerulescence for $\mathrm{Cd}, \mathrm{Ni}$. $\mathrm{Pb}$, and $\mathrm{Zn}$; T. goesingense and T.ochroleucum for $\mathrm{Ni}$ and $\mathrm{Zn}$ and T.rotundifolium for $\mathrm{Ni}, \mathrm{Pb}$ and $\mathrm{Zn}$ (Prasad and Freitas, 2003).

Plants that accumulate and exclude metals have tremendous potential for application in remediation of metals in the environment. Significant progress has been achieved in phytoremediation (Vangronsveld and Cunningham, 1998; Glass, 1999; Terry and Bañuelos, 2000; McCutcheon and Schnoor, 2003; Prasad, 2003, 2004a,b). This process involves raising plants hydroponically and transplanting them into metal-polluted waters where the plants absorb and concentrate the metals in their roots and shoots. As they become saturated with the metal contaminants, roots or whole plants are harvested for disposal. The phytoextraction 
Table 2. Nickel in plant cell and environment - from adaptive physiology to phytomanagement.

This listed information pertains to $\mathrm{Ni}$ and its presence in the environment as a contaminant, and covers topics such as uptake, accumulation, phytotoxicity, physiology and biochemistry of toxicity and tolerance in plants, biochemical chraracterization and phytomanagement.

\begin{tabular}{|c|c|c|}
\hline Function & Authors & Year \\
\hline \multicolumn{3}{|l|}{ Environmental contaminant } \\
\hline Nickel in rocks, soils, waters and plants adjacent to the Chorchanskaya & Doksopulo & 1961 \\
\hline Impact of nickel contamination on the production of vegetables on an organic soil, Ontario, Canada & Frank et al. & 1982 \\
\hline Zinc, copper and nickel concentrations in soil extracts and crops grown on four soils treated with metalloaded sewage sludges & Sanders et al. & 1987 \\
\hline Uptake of nickel and cadmium by vegetables grown on soil amended with different sewage sludges & Singh et al. & 1989 \\
\hline Nickel in the terrestrial environment & McIlveen and Negusanti & 1994 \\
\hline Trace metal bioavailability in municipal solid waste and sewage sludge composts & Pichtel and Anderson & 1997 \\
\hline $\begin{array}{l}\text { Groundwater composition near the nickel-copper smelting industry on the Kola Peninsula, central Barents Region (NW Russia and NE } \\
\text { Norway) }\end{array}$ & Patrice et al. & 1998 \\
\hline Heavy metals in soils and plants of serpentine and industrial sites of Albania & Shallari et al. & 1998 \\
\hline Urinary nickel as bioindicator of $\mathrm{Ni}$ exposure of workers in a galvanizing plant in Brazil & Siqueira et al. & 1998 \\
\hline Influence of nickel contaminated soils on lettuce and tomatoes & Zdenek Poulik et al. & 1999 \\
\hline Clinical toxicology of nickel & Barceloux & 1999 \\
\hline Nitrogen transformation and microbial biomass content in soil contaminated with nickel and cadmium from industrial wastewater irrigation & Antil et al. & 2001 \\
\hline Contemporary use of $\mathrm{Ni}$ and $\mathrm{Bi}$ in hot-dip galvanizing & Fratesi et al. & 2002 \\
\hline Influence of nickel-contaminated soils on fenugreek (Trigonella corniculata L.) growth and mineral composition & Parida et al. & 2003 \\
\hline Nnickel speciation in Sebertia acuminata, a plant growing on a lateritic soil of New Caledonia & Perrier et al. & 2004 \\
\hline Sulphur dioxide adsorption in Scots pine canopies exposed to high ammonia emissions near a Cu-Ni smelter in SW Finland & Derome et al. & 2004 \\
\hline Speciation studies of nickel and chromium in wastewater from an electroplating plant. & Jackson et al. & 2004 \\
\hline
\end{tabular}

Accumulation

Accumulators from Western Australia.

Accumulators from from New Caledonia

Kelly et al.

Accumulation by Rinorea bengalensis (Wall.)

Brooks et al.

Accumulation in three Australian plants growing on the mineralized sites

Farago et al.

Accumulation by European species of the genus Alyssum

Brooks et al.

Selective accumulation of nickel II ions in plants

Still et al.

Accumulation by soybean from sludge-amended soil

Reddy and Dunn

Accumulation by Psychotria species from the pacific Basin

Baker et al.

Accumulation by species of Thlaspi L., Cochlearia L.,

Reeves

Stackhousia tryonii Bailey: accumulator, serpentinite-endemic species of central Queensland

Batianoff et al.

Accumulation mechanisms and tolerance

Gabbrielli and Vergnano 1991

Accumulation by tropical plants growing around an industrial area

Rao and Dubey

Accumulation by serpentine plants.

Reeves

Accumulation in the foliage of plants growing in the vicinity of an oil-fired power plant

William et al.

Accumulation by western North American genera

Reeves et al.

Accumulation in rice plants- effects on mineral nutrition and possible interactions of abscisic and gibberellic acids

Rubio et al. 


\begin{tabular}{|c|c|c|}
\hline \multicolumn{3}{|l|}{ Uptake } \\
\hline Uptake kinetics of nickel using intact soybean seedlings & Cataldo et al. & 1978 \\
\hline Nickel uptake by Alyssum species & Morrison et al. & 1980 \\
\hline $\begin{array}{l}\text { Nickel uptake by Californian Streptanthus and Caulanthus with particular reference to the hyperaccumulator, S. polygaloides Gray } \\
\text { (Brassicaceae) } \\
\text { Metal ion uptake by plants of genus Aalyssum }\end{array}$ & $\begin{array}{l}\text { Reeves et al. } \\
\text { Fiuman et al. }\end{array}$ & $\begin{array}{l}1981 \\
1983\end{array}$ \\
\hline Uptake of nickel by species of Alyssum bornmuellera and other genera of Old World Tribus Alyssae & Reeves et al. & 1983 \\
\hline $\begin{array}{l}\text { Investigation of effects of cadmium, lead, nickel and vanadium contamination on the uptake and transport processes in cucumber plants by } \\
\text { TXRF spectrometry }\end{array}$ & Varga et al. & 1999 \\
\hline Chelator (EDTA and HEDTA) effects on Ni uptake by Helianthus annuиs & Hong and Cutright & 2001 \\
\hline Assessment of plant uptake of radioactive nickel from soils & Denys et al. & 2002 \\
\hline \multicolumn{3}{|l|}{ Transport } \\
\hline The role of metal transport and tolerance in nickel hyperaccumulation by Thlaspi goesingense halacsy & Kramer et al. & 1977 \\
\hline Comparative phloem mobility of nickel in nonsenescent plants & Neumann Chamel & 1986 \\
\hline Long-distance transport of cobalt and nickel in maturing wheat & Zeller and Feller & 1999 \\
\hline Nickel transport systems in microorganisms & Eitinger et al. & 2000 \\
\hline
\end{tabular}

\begin{tabular}{lll}
\hline Phytotoxicity & \\
\hline $\begin{array}{l}\text { A methodology for establishing phytotoxicity criteria for chromium, copper, nickel and zinc in agricultural and application of municipal } \\
\text { sewage sludge }\end{array}$ & Chang et al. & 1992
\end{tabular}
sewage sludge

A comparative analysis of element composition of roots and leaves of barley seedlings grown in the presence of toxic cadmium,

Brune and Dietz

molybdenum, nickel and zinc concentratiuons

Tolerance
Copper and nickel tolerance in Typha latifolia clones from contaminated and uncontaminated environments

Taylor and Crowder

Differential tolerance of three cultivars of Agrostis capillaris L. to cadmium, copper, lead, nickel and zinc

Taylor and Crowder

Comparison of two serpentine species with different nickel tolerance strategies

Symenoides et al.

1985

The tolerance of Empetrum nigrum to copper and nickel

Gabbrielli et al.

Biochemical characterization

Charcterization of of nickel compounds in Alyssum bertolonii

Monni et al.

2000

Isolation and identification of a citrate complex of nickel from plants

Pelosi et al.

The relation between nickel and citric acid in some nickel-accumulating plants

Lee et al.

Nature of nickel complexes in Psychotria douarrei and other nickel-accumulating plants

Lee et al.

Kersten et al.

The amino acid content of Hybanthus floribundus, a nickel accumulating plant and the difficulty of detecting nickel amino acid complexes by chromatographic methods

Farago et al.

Biochemical form of nickel in alfalfa

Theisen and Blincoe

Isolation and partial characterization of nickel complexes in higher plants.

Theisen and Blincoe

Organic constituents and complexation of nickel (II) in soybean xylem exudates

Cataldo et al.

Characterization of the nickel-rich extract from the nickel hyperaccumulator Dichapetalum gelonioides

Homer et al.

Bioaccumulation and toxicology of nickel: implications for wild mammals and birds

Outridge and Sheuhammer

Concentration profiles of arsenic, cadmium, chromium,copper, lead, mercury, nickel, zinc, vanadium and polynuclear aromatic hydrocarbons (PAH) in forest soil beside an urban road

Munch

Localisation of nickel in epidermal subsidiary cells of leaves of Thlaspi montanum var. siskiyouense (Brassicaceae) using energy-dispersive Heath et al.

Organic costituents and complexation of nickel, iron, cadmium and plutonium in soybean xylem exudates

Cataldo et al.

Nnickel-binding proteins

Watt and. Ludden

The role of histidine in nickel hyperaccumulation in Thlaspi goesingense (Halácsy)

Pearsans et al.

Relative Abundance of nickel in the leaf epidermis of eight hyperaccumulators: evidence that the metal is excluded from both guard cells and trichomes

Psaras et al.

Nuclear microprobe studies of elemental distribution in apical leaves of the Ni hyperaccumulator Berkhya coddii

Mesjasz-Przybylowicz et al.

Hyphenated technique for investigation of nickel complexation by citric acid in xylem sap of cucumber plants

Gasparics et al. 
Nickel contamination affects growth and secondary metabolite composition of St. John's wort (Hypericum perforatum L.)

Organic acid complexation, heavy metal distribution and the effect of ATPase inhibition in hairy roots of hyperaccumulator plant species

Boominathan et al.

Hyperaccumulation of nickel by AlyssumLinnaeua

Brooks et al.

Comparative studies of nickel, cobalt and copper uptake by some nickel hyperaccumulators of the genus Alyssum

Homer et al.

Nickel hyperaccumulated by Thlaspi montanum var. montanum is acutely toxic to an insect herbivore

Boyd and Martens.

Nickel hyperaccumulation defends Streptanthus polygaloides (Brassicaceae) against pathogens

Boyd et al.

The ecological significance of nickel hyperaccumulation: a plant chemical defense

Martens and Boyd

Hyperaccumulation, complexation and distribution of nickel in Sebertia acuminata

Sagner et al.

Nnickel hyperaccumulation by Thlaspi montanum var. montanum (Brassicaceae): a constitutive trait

Boyd et al.

The significance of metal hyperaccumulation for biotic interactions

Nickel hyperaccumulation in the Serpentine Flora of Cuba

Reeves et al.,

Metal hyperaccumulation: a model system for co-evolutionary studies

Pollard

The role of root exudates in nickel hyperaccumulation and tolerance in accumulator and non-accumulator species of Thlaspi

Salt et al.

Elemental distribution in Senecio anomalochrous, a Ni hyperaccumulator from South Africa

Mesjasz-Przybylo-wicz et al. 2001

Rhizosphere characteristics of indigenously-growing nickel hyperaccumulator and excluder plants on serpentine soil

Wenzel et al.

\section{Indicator}

Hybanthus floribundus (Lindl.) F. Muell. indicator and accumulator plant

Cole

Sebertia acuminata: a nickel-indicator and accumulator from New Caledonia

Jaffre et al.

Alyssum bertolonii Desv. a nickel-indicator and accumulator

Vergnano et al.

European species of Thlaspi L. (Cruciferae) as indicators of nickel and zinc

Reeves and Brooks

A new nickelophilous species of Alyssum (Cruciferae) from Portugal

Dudley

Molecular biology of nickel carcinogenesis

\section{Elemental defence}

Deterrence of herbivory by zinc hyperaccumulation in Thlaspi caerulescens (Brassicaceae)

Pollard and Baker

Aphids are unaffected by the elemental defence of the nickel hyperaccumulator Streptanthus polygaloides (Brassicaceae)

Boyd and Martens

Phytoenrichment of soil Ni content by Sebertia acuminata in New Caledonia and the concept of elemental allelopathy

Boyd and Jaffré

Responses of generalist predators fed high-Ni Melanotrichus boydi (Heteroptera: Miridae): elemental defense against the third trophic level Boyd and Wall

Modelling the interactive effects of aluminum, cadmium, manganese, nickel and zinc stress using the weibull frequency distribution

Taylor et al.

Metal-metal interactions in accumulation of $\mathrm{V}^{5+}, \mathrm{Ni}^{2+}, \mathrm{Mo}^{6+}, \mathrm{Mn}^{2+}$ and $\mathrm{Cu}^{2+}$ in under- and above-ground parts of Sinapis alba

\begin{tabular}{|c|c|c|}
\hline \multicolumn{3}{|l|}{ Mycorrhizal association } \\
\hline Response of ectomycorrhizal Quercus rubra to soil cadmium, nickel and lead & Dixon & 1988 \\
\hline Survival of the indigenous population of Rhizobium leguminosarum biovar trifolii in soil spiked with $\mathrm{Cd}, \mathrm{Zn}, \mathrm{Cu}$ and Ni salts & Chaudri et al. & 1992 \\
\hline $\begin{array}{l}\text { Effects of chromium and nickel on growth of the ectomycorrhizal fungus Pisolithus and formation of ectomycorrhizas on } \\
\text { Eucalyptus urophylla S.T. Blake }\end{array}$ & Aggangan et al. & 1998 \\
\hline Arbuscular mycorrhiza of Berkheya coddii and other Ni-hyperaccumulating members of Asteraceae from ultramafic soils in South Africa & $\begin{array}{l}\text { Turnau and Mesjasz- } \\
\text { Przybylowicz }\end{array}$ & 2003 \\
\hline
\end{tabular}


Is nickel a universal component of plant ureases?

Carbohydrate levels and photo assimilate export from leaves of Phaseolus vulgaris to excess cobalt, nickel and zinc

Effects of excess cobalt, nickel and zinc on the water relations of Phaseolus vulgaris

The chemical form and physiological function of nickel in some Iberian Alyssum species

Effects of heavy metals on the growth and mineral composition of a nickel hyperaccumulator

Nnickel-induced stimulation of growth, heterocyst differentiation, $14 \mathrm{CO} 2$ uptake and nitrogenase activity in Nostoc muscorum

Effects of nickel and copper mixtures on tomato in sand culture

Effects of vanadium, nickel and sulphur dioxide on polar lipid biosynthesis in jack pine

Impairment of photosystem II activity at the level of secondary quinone electron-acceptor in chloroplasts treated with cobalt, nickel and Mohanty et al. zinc ions.

Effect of nickel on photosynthesis and the enzymes of the photosynthetic carbon reduction cycle in Pigeon pea (Cajanus cajan)

Effect of nickel on the lipid composition, Mg-ATPase activity and fluidity of plasma membranes from rice, Oryza sativa cv. Bahia shoots

Effect of nickel on ethylene biosynthesis in soybean

In vivo and in vitro effects of nickel and cadmium on the plasmalemma ATPase from rice (Oryza sativa L.) shoots and roots

Effect of cadmium and nickel on mobilisation of food reserves and activities of hydrolytic enzymes in germinating pigeon pea seeds

In vivo response of photosynthetic apparatus of Phaseolus vulgaris to nickel toxicity

Influence of cadmium and nickel on photosynthesis and water relations in wheat leaves of differential insertion level

Influence of cadmium and nickel on growth, net photosynthesis and carbohydrate distribution in rice plants

Treatment of chromium and nickel in wastewater by using aquatic plants

Hydrogen uptake in Nostoc strain PCC 73102: Effects of nickel, hydrogen,carbon and nitrogen

Free histidine as a chelator in plants that accumulate nickel.

Effect of heavy metals on the growth and mineral composition of nickel hyperaccumulation

Removal of nickel ions from aqueous solution by biomass and silica-immobilized biomass of Medicago sativa (Alfalfa)

Phytofiltration of hazardous cadmium, chromium, lead and zinc ions by biomass of Medicago sativa (Alfalfa)

Phytoremediation

Influence of nickel on organic acid transport in xylem sap of cucumber

Influence of Ni supply on growth and nitrogen metabolism of Brassica napus L. grown with NH4NO3 or urea as N source

Effects of chromium and nickel on germination and growth in tolerant and non-tolerant populations of Echinochloa colona (L.)

Effects of nickel concentration in the nutrient solution on the nitrogen assimilation and growth of tomato seedlings in hydroponic culture supplied with urea or nitrate as the sole nitrogen source

Effects of chromium and nickel on germination and growth in tolerant and non-tolerant populations of Echinochloa colona (L.)

Effects of nickel concentration in the nutrient solution on the nitrogen assimilation and growth of tomato seedlings in hydroponic culture supplied with urea or nitrate as the sole nitrogen source

Effect of mixed cadmium, copper, nickel and zinc at different $\mathrm{pHs}$ upon alfalfa growth and heavy metal uptake

Phytoremediation of metals using transgenic plants

Lead and nickel removal using Microspora and Lemna minor

Relationship between the chemical form of nickel applied to the soil and its uptake and toxicity to barley plants (Hordeum vulgare L.)

Polacco

Samarakoon and Rauser

Rauser et al.

Brooks et al.

Varennes et al.

Rai and Raizada.

Hale et al.

Khan et al.

Shoeran et al

Ros et al.

Pnnazio and Roggero

Ros et al.

Bishnoi et al.

Krupa et al.

Bishnoi et al.

Moya et al.

Srivastav et al.

Oxelfelt et al.

Krämer et al.

Verennes A.de et al.

Gardea-Torresdey et al.

Gardea-Torresdey et al.

Salt et al.

Tat et al.

Gerend et al.

Grout et al.

Tan et al.

Rout et al.

Tan et al.

Peralta-Videa et al.

Pilon-Smits and Pilon

Nicholas et al.

Molas and Baran

\section{Phytomining and Phytomanagement}

Nickel phytomining

Nicks and Chambers

Chaney et al.

Phytomining

Brooks, et al.

Anderson et al.

Robinson et al.

The nickel hyperaccumulator plant Alyssum bertolonii as a potential agent for phytoremediation and phytomining of nickel

Robinson et al.

The potential of the high biomass nickel hyperaccumulator Berkheya coddii for phytoremediation and phytomining

Robinson et al. 
process involves the use of plants to facilitate the removal of metal contaminants from a soil matrix. In practice, metalaccumulating plants are seeded or transplanted into metalpolluted soil and are cultivated using established agricultural practices. If metal availability in the soil is not adequate for sufficient plant uptake, chelates or acidifying agents would be applied to liberate them into the soil solution. Use of soil amendments such as synthetics (ammonium thiocyanate) and natural zeolites have yielded promising results. Synthetic cross-linked polyacrylates (hydrogels) have protected plant roots from heavy metals toxicity and prevented the entry of toxic metals into roots. After sufficient plant growth and metal accumulation, the above-ground portions of the plant are harvested and removed, resulting the permanent removal of metals from the site. Soil metals should also be bioavailable, or subject to absorption by plant roots. Chemicals that are suggested for this purpose include various acidifying agents, fertilizer salts and chelating materials. The retention of metals to by soil organic matter is also weaker at low $\mathrm{pH}$, resulting in more available metal in the soil solution for root absorption. It is suggested that the phytoextraction process is enhanced when metal availability to plant roots is facilitated through the addition of acidifying agents to the soil. Chelates are used to enhance the phytoextraction of a number of metal contaminants including $\mathrm{Cd}, \mathrm{Cu}, \mathrm{Ni}, \mathrm{Pb}$, and $\mathrm{Zn}$.

$\mathrm{Ni}$ tolerant plants/Ni accumulators either accumulate or exclude metals. Hence, plants with a reduced capacity to accumulate toxic metals if edible, should be a concern for human health. In contrast, plants with an enhanced capacity to accumulate toxic metals can help in phytoremediation technologies. Thus, knowledge of how plants can specifically accumulate or exclude essential elements and toxic metals, particularly in case of Ni tolerant plants or accumulators can be exploited for the selection of species that are appropriate for use in phytoremediation. This includes knowledge on bioavailability of metals, rhizospheric processes and root uptake, as well as on translocation to and processing/storage in the above-ground parts of the plant. Use of plants that hyperaccumulate specific metals and control and/or transform organic pollutants is gaining considerable significance in contemporary phytotechnology (table 2).

$\mathrm{Ni}$ tolerant plants and $\mathrm{Ni}$ accumulators have been found to be useful in phytotechnologies all over the word for transformation and containment of inorganic and organic pollutants including radionuclides (table 2). However, ecosystem design and management, investigations related to rhizosphere biotechnology, processes involved in the evolution of eco- systems and engineering of plant metabolism for enhancing the adaptive ecophysiology still remain a challenging task particularly with regard to the management of the phytomass and recycling (figures 2 and 3).

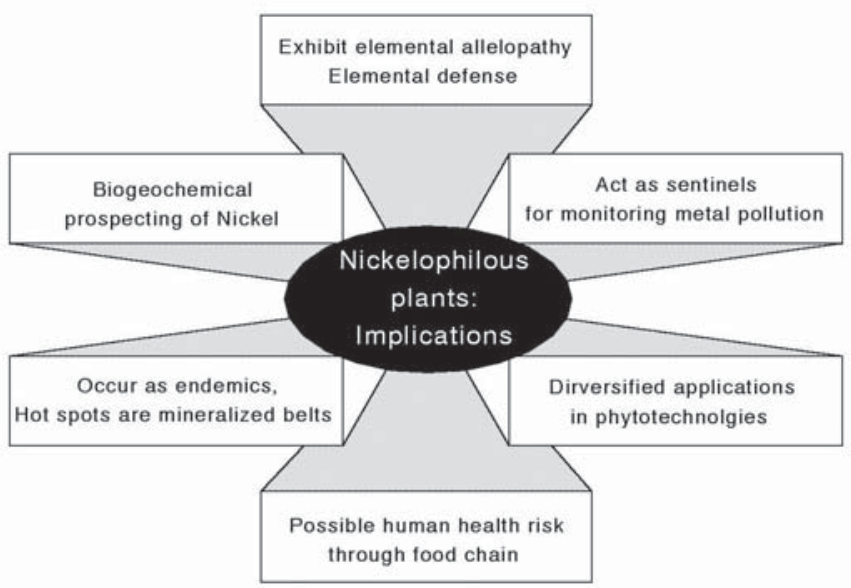

Figure 1. Environmental implications of nickelophilous plants scope and limitations

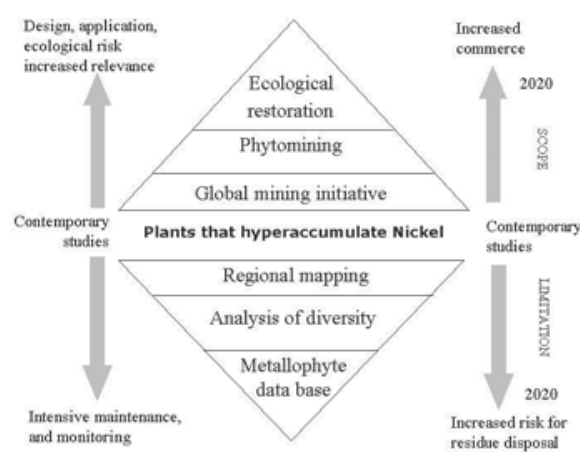

Figure 2. Advantages and limitations of using invasive and non-invasive plants (indigenous and alien) in phytotechnologies. (Based on McCutcheon and Schnoor, 2003 ).

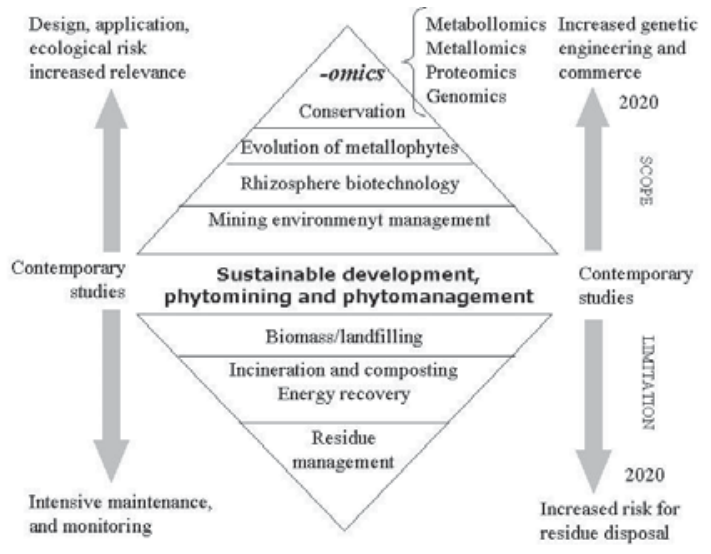

Figure 3. In order to move ahead in phytotechnologies: existing gaps in our knowledge must be thoroughly investigated with the available modern tools (Based on McCutcheon and Schnoor, 2003). 


\section{REFERENCES}

Aggangan NS, Dell B Malajczuk N (1998) Effects of chromium and nickel on growth of the ectomycorrhizal fungus Pisolithus and formation of ectomycorrhizas on Eucalyptus urophylla S.T. Blake Geoderma 84:15-27.

Anderson TR, Howes AW, Slatter K, Dutton MF (1997) Studies on the nickel hyperaccumulator, Berkheya coddii. In: Jaffre T, Reeves RD, Becquer T (eds), The ecology of ultramafic and metalliferous areas. Proceedings of the Second International Conference on Serpentine Ecology, Noumea (1995), pp. 2261-266.

Antil RS, Gupta AP, Narwal RP (2001) Nitrogen transformation and microbial biomass content in soil contaminated with nickel and cadmium from industrial wastewater irrigation. Urban Water 3:299-302.

Arianoutsou M, Rundel PW, Berry WL (1993) Serpentine endemics as biological indicators of soil elemental concentrations. In: Markert B (ed), Plants as biomonitors. Indicators for Heavy Metals in the Terrestrial Environment, pp.179-189. VCH-Publisher, Weinheim.

Augustyniak M, Mesjasz-Przybylowicz J, Nakonieczny M, Dybowska M, Przybylowicz W, Migula P (2002) Food relations between Chrysolina pardalina and Berkheya coddii, a nickel hyperaccumulator from South African ultramafic outcrops. Fresen Environ. Bull. 11:85-90.

Axtell NR, Steven PK Sternberg SPK, Claussen K (2003) Lead and nickel removal using Microspora and Lemna minor. Bioresour. Technol. 89:41-48.

Baker AJM, McGrath SP, Sidli CMD, Reeves RD (1994) The possibility of in situ heavy metal decontamination of polluted soils using crops of metal-accumulating plants. Resour. Cons. Recycl. 11:41-49.

Baker AJM, Reeves RD, Hajar ASM (1994) Heavy metal accumulation and tolerance in British populations of the metallophyte Thlaspi caerulescens J. \& C. Presl (Brassicaceae). New Phytol. 127: 61-68.

Baker AJM, Brooks RP, Kersten WJ (1985) Accumulation of nickel by Psychotria species from the pacific Basin. Taxon 34:89-95.

Barcelo J, Poschenrieder C (2002) Fast root growth responses, root exudates, and internal detoxification as clues to the mechanisms of aluminium toxicity and resistance: a review. Environ. Exp. Bot. 48:75-92.

Barceloux DG (1999) Nickel. Clinical Toxicol. 37:239-258.

Batianoff GN, Reeves RD, Specht RL (1990) Stackhousia tryonii Bailey: a nickel accumulation serpentinite-endemic species of central Queensland. Aust. J. Bot. 38:121.

Belovsky GE and Schmitz OJ (1994) Plant defenses and optimal foraging by mammalian herbivores. J. Mammal. 75: 816-832.

Berenbaum MR (1995) The chemistry of defense: theory and practice. In: Eisner T, Meinwald J (eds), Chemical ecology. The Chemistry of Biotic Interaction, pp.1-16. National Academy Press, Washington DC, USA.

Bishnoi NR, Sheoran IS, Singh R (1993) Influence of cadmium and nickel on photosynthesis and water relations in wheat leaves of differential insertion level. Photosynthetica 28:473-479.
Bishnoi NR, Sheoran I, Sand Singh R (1993) Effect of cadmium and nickel on mobilisation of food reserves and activities of hydrolytic enzymes in germinating pigeon pea seeds. Biol. Plant. 35:583-589.

Boominathan R, Doran PM (2003) Organic acid complexation, heavy metal distribution and the effect of ATPase inhibition in hairy roots of hyperaccumulator plant species J. Biotechnol. 101:131-146.

Boyd RS (1998) Hyperaccumulation as a plant defensive strategy. In: Brooks RR (ed), Plants that hyperaccumulate Heavy Metals, pp. 181-201. CAB International, New York.

Boyd RS and Martens SN (1998) Nickel hyperaccumulation by Thlaspi montanum var. montanum (Brassicaceae): a constitutive trait. Am. J. Bot. 85:259-265.

Boyd RS, Martens SN (1998) The significance of metal hyperaccumulation for biotic interactions. Chemoecology 8:1-7.

Boyd RS, Martens SN (1999) Aphids are unaffected by the elemental defence of the nickel hyperaccumulator Streptanthus polygaloides (Brassicaceae). Chemoecology 9:1-7

Boyd RS, Wall MA (2001) Responses of generalist predators fed high-Ni Melanotrichus boydi (Heteroptera: Miridae): elemental defense against the third trophic level. Am. Midl. Nat. 146:186-198.

Boyd RS, Jaffré T (2001) Phytoenrichment of soil Ni content by Sebertia acuminata in New Caledonia and the concept of elemental allelopathy. S. Afr. J. Sci. 97:535-538.

Boyd RS, Martens SN (1992) The raison d'être for metal hyperaccumuation by plants. In: Baker AJM, Proctor J, Reeves RD (eds), The vegetation of ultramafic (serpentine) soils, pp. 279-289. Intercept Ltd, GB-Andover.

Boyd RS, Martens SN (1994) Nickel hyperaccumulated by Thlaspi montanum var. montanum is acutely toxic to an insect herbivore. Oikos 70:21-25.

Boyd RS, Martens SN (1998) The significance of metal hyperaccumulation for biotic interactions. Chemoecology 8:1-7.

Boyd RS, Martens SN (1998). Nickel hyperaccumulation by Thlaspi montanum var. montanum (Brassicaceae): a constitutive trait. Am. J. Bot. 85:259-265.

Boyd RS, Shaw JJ and Martens SN (1994) Nickel hyperaccumulation in S.polygaloids (Brassicaceae) as a defense against pathogens. Am. J. Bot. 81:294-300.

Brooks RR (1987) Serpentine and its vegetation: A multidisciplinary approach. Discorides Press, Portland, Oregon.

Brooks RR (1998) Plants that hyperaccumulate heavy metals. CAB International. Wallingford.

Brooks RR, Wither ED (1977) Nickel accumulation by Rinorea bengalensis (Wall.) O.K. J. Geochem. Expl. 7:295-300.

Brooks RR (1979-1980) Indicator plants for mineral prospecting - a critique. J. Geochem. Expl. 12:67-78.

Brooks RR, Chambers MF, Nicks LJ, Robinson BH, Jovanovic D, Radovic R, Mares L, Stankovic M, Markovic B (1998). Nickel hydrogenation catalyst for tallow hydrogenation and for the selective hydrogenation of sunflower seed oil and soybean oil. Catalysis Today 43:21-28.

Brooks RR, Chambers MF, Nicks LJ, Robinson BH (1998) Phytomining. Trends Plant Sci. 3:359-362. 
Brooks RR, Lee J, Reeves RD, Jaffre T (1977) Detection of nickeliferous rocks by analysis of herbarium specimens of indicator plants. J. Geochem. Expl. 7:49-57.

Brooks RR, Morrison RS, Reeves RD, Dudley TR, Akman Y (1979). Hyperaccumulation of nickel by Alyssum Linnaeus (Cruciferae). Proc. R. Soc. London, Ser B 203:387-403.

Brooks RR, Ratford. CC (1978) Nickel accumulation by European species of the genus Alyssum. Proc. R. Soc. London, Ser B 200:217-224.

Brooks RR, Robinson BH (1998) The potential use of hyperaccumulators and other plants for phytomining. In: Brooks RR (ed), Plants that hyperaccumulate heavy metals - their role in phytoremediation, microbiology, archaeology, mineral exploration and phytomining, pp 327-356. CAB, Cambridge, UK.

Brooks RR, Shaw S, Marfil AA (1981) The chemical form and physiological function of nickel in some Iberian Alyssum species. Physiol. Plant. 51:167-170.

Brooks RR, Trow JM, Blviken B (1979) Biogeochemical anomalies in fennoscandia: A study of copper, lead and nickel levels in Melandrium dioicum and Viscaria alpina J. Geochem. Expl. 11:73-87.

Brune A, Dietz KJ (1995) A comparative analysis of element composition of roots and leaves of barley seedlings grown in the presence of toxic cadmium, molybdenum, nickel and zinc concentratiuons. J. Plant Nutr. 18:853-868.

Bulmer CE, Lavkulich LM (1994) Pedogenic and geochemical processes of ultramafic soils along a climatic gradient in southwestern British Columbia. Can. J. Soil Sci. $74: 165-177$.

Cataldo DA, Garland TR, Wildung RE (1978) Nickel in plants. I. Uptake kinetics using intact soybean seedlings. Plant Physiol. 62:563-565.

Cataldo DA, McFadden KM, Garland TR, Wildung RE (1998). Organic costituents and complexation of nickel, iron, cadmium and plutonium in soybean xylem exudates. Plant Physiol. 86:734-739.

Chaney RL, Angle JS, Baker AJM, Li YM (1999) Method for phytomining of nickel, cobalt and other metals from soil. US Patent, 5944872.

Chaney RL, Lee YM, Brown SL, Homer FA, Malik M, Angle JS, Baker AJM, Reeves RD, Chin M (2000) Improving metal hyperaccumulator wild plants to develop commercial phytoextraction systems: approaches and progress. In: Terry N, Banuelos G (eds), Phytoremediation of contaminated soil and water, pp.129-158. CRC, Boca Raton, Fla., USA.

Chang AC, Granato TC, Page AL (1992) A methadology for establishing phytotoxicity criteria for chromium, copper, nickel and zinc in agricultural and application of municipal sewage suldge. J. Envir. Qual. 21:521-536.

Cole MM(1974). Geobotanical and biogeochemical investigation in the sclerophyllous woodland and scrub associations of the eastern Goldfields area of Western Australia with partial reference to the role of Hybanthus floribundus (Lindl.) F. Muell. A nickel indicator and accumulator plant. J. Appl. Ecol. 10:269-320.

Costa M (1998) Molecular biology of nickel carcinogenesis. Fresenius J. Anal. Chem. 361:381-385.
Cunningham SD, Ow DW (1996) Promises and prospects of phytoremediation. Plant Physiol. 110:715-719.

de Caritat P, Danilova S, Ger YJ, Reimann C, Storr G (1998) Groundwater composition near the nickel-copper smelting industry on the Kola Peninsula, central Barents Region (NW Russia and NE Norway). J. Hydrol. 208:92-107.

De Varennes A, Torres MO, Coutinho JF, Rocha MMGS, Neto MMPM (1996) Effects of heavy metals on the growth and mineral composition of a nickel hyperaccumulator. J. Plant Nutr. 19:669-676.

Denys S, Echevarria G, Leclerc-Cessac E, Massoura S, Morel JL (2002) Assessment of plant uptake of radioactive nickel from soils. J. Environ. Radioactiv. 62:195-205.

Dixon AFG (1985) Aphid Ecology. Blackie, GB-London.

Dixon RK (1988) Response of ectomycorrhizal Quercus rubra to soil cadmium, nickel and lead Soil Biol. Biochem. 20:555-559.

Doksopulo EP (1961) Nickel in rocks, soils, waters and plants adjacent to the Chorchanskaya Group. Izdatel Tbiliskovo Universiteta, 1961, Tbilisi.

Dudley TR (1986) A new nickelophilous species of Alyssum (Cruciferae) from Portugal, Alyssum pintodasilvae. Fedd. Repertorium 97:135-138.

Dudley TR (1986) A nickel hyperaccumulating species of Alyssum (Cruciferae) from Spain: Alyssum malacitanum (Rivas Goday). Fedd. Repertorium 97:139-142.

Eitinger T, Friedrich B (1994) A topological model for the high affinity nickel transporter of Alcaligenes eutrophus. Mol. Microbiol. 12:1025-1032.

Eitinger T, Mandrand-Berthelot MA (2000) Nickel transport systems in microorganisms. Arch. Microbiol. 173:1-9.

Enik TR, Mihucz VG, Varga A, Zray G, Cseh E (1999) Effect of lead, nickel and vanadium contamination on organic acid transport in xylem sap of cucumber J. Inorg. Biochem. 75:219-223.

Ernst WHO, Schat H, Verkleij JAC (1990) Evolutionary biology of metal resistance in Silene vulgaris. Evol. Trends Plants 4:45-51.

Farago ME, Clark AJ, Pitt MJ (1977) Plants which accumulate metals. Part I. The metal content of three australian plants growing over mineralised sites. Inorg. Chim. Acta 24:53-56.

Farago ME, Cole MM (1988) Nickel and plants. In: Siegel H, Siegel A (eds), Metal Ions in Biological Systems, nickel and its Role in Biology, vol.23, pp47-90. Marcel Dekker, New York.

Farago ME, Mahmood I, Clark AJ (1980) The amino acid content of Hybanthus floribundus, a nickel accumulating plant and the difficulty of detecting nickel amino acid complexes by chromatographic methods. Inorg. Nucl. Chem. Lett. 16:481-484.

Frank R, Stonefield KI, Suda P, Potter JW (1982) Impact of nickel contamination on the production of vegetables on an organic soil, Ontario, Canada, 1980-1981. Sci. Total Environ. 26:41-65.

Fratesi R, Ruffini N, Malavolta M, Bellezze T (2002) Contemporary use of $\mathrm{Ni}$ and $\mathrm{Bi}$ in hot-dip galvanizing. Surf. Coat. Technol. 157:34-39. 
Freitas H, Prasad MNV, Pratas J (2004) Plant community tolerant to trace elements growing on the degraded soils of São Domingos mine in the south east of Portugal: environmental implications. Environ. Int. 30:65-72.

Gabbrielli R, Gremigni P, Morassi LB, Pandolfini T, Bonatti PM (1997) Some aspects of Ni tolerance in Alysum bertolonii Desv.: strategies of metal distribution and accumulation. In: Jaffré T, Reeves RD, Becquer T (eds), Ecologie des Milieux sur Roches Ultramafiques et sur Sols Métallifères. The ecology of ultramafic and metalliferous areas, pp 225-227. Orstom, Numéa.

Gabbrielli R, Mattioni C, Vergnano O (1991) Accumulation mechanisms and heavy metal tolerance of a nickel hyperaccumulator. J. Plant Nutr. 14:1067-1080.

Gabbrielli R, Pandolfini T, Vergnano O, Palandri MR (1990) Comparison of two serpentine species with different nickel tolerance strategies. Plant Soil 122:271-277.

Gardea-Torresdey JL, Tiemann KJ, Gonzalez JH, Cano-Aguilera I, Henning JA, Townsend MS (1996) Removal of nickel ions from aqueous solution by biomass and silica- immobilized biomass of Medicago sativa (alfalfa). J. Hazard. Mat. 49:205-216.

Gaur A, Adholeya A (2004) Prospects of arbuscular mycorrhizal fungi in phytoremediation of heavy metal contaminated soils. Curr. Sci. 86:528-534.

Gerend JS, Sattelmacher B (1999) Influence of Ni Supply on Growth and Nitrogen Metabolism of Brassica napusL. Grown with $\mathrm{NH}_{4} \mathrm{NO}_{3}$ or urea as N Source. Ann. Bot. 83:65-71.

Glass DJ (1999) U.S and international markets for phytoremediation, 1999-2000. D.J.Glass Associates Inc. Needham, MA, USA.

Gonçalves S, Gonçalves MT, Freitas H, Martins-Loução MA (1995) Mycorrhizae in a portuguese serpentine community. In: Jaffré T, Reeves RD, Becquer T (eds), The ecology of Ultramafic and Metalliferous Areas, pp. 87-89. ORSTOM, Nouméa, Doc. Sci. Tech. III 2.

Gonçalves SC, Martins-Loução MA, Freitas H (2001) Arbuscular mycorrhizas of Festuca brigantina, an endemic serpentinophyte from Portugal. South Afr. J. Sci. 97: 571-572.

Gregurek D, Reimann C, Stumpfl EF (1998) Trace elements and precious metals in snow samples from the immediate vicinity of nickel processing plants, Kola Peninsula, northwest Russia. Environ. Pollut. 102:221-232.

Gregurek D, Reimann C, Eugen F(1998). Stumpfl Mineralogical fingerprints of industrial emissions - an example from Ni mining and smelting on the Kola Peninsula, NW Russia. Sci. Total Environ. 221:189-200.

Hale JC, Ormrod DP, Laffey PJ, Allen OB (1985) Effects of nickel and copper mixtures on tomato in sand culture. Environ. Pollut. Series A, Ecological and Biological 39:53-69.

Heath SM, Southworth D, Allura JAD (1997) Localization of nickel in epidermal subsidiary cells of leaves of Thlaspi montanum var. siskiyouense (Brassicaceae) using energy-dispersive X-ray microanalysis. Int. J. Plant Sci. 158:184-188.

Homer FA, Morrison RS, Brooks RR, Clemens J, Reeves RD (1991) Comparative studies of nickel, cobalt and copper uptake by some nickel hyperaccumulators of the genus Alyssum. Plant Soil 138:195-205.

Homer FA, Reeves RD, Brooks RR, Baker AJM (1991) Characterization of the nickel-rich extract from the nickel hyperaccumulator Dichapetalum gelonioides. Phytochemistry 30:2141-2145.

Homer FA, Morrison RS, Brooks RR, Clemens J, Reeves RD (1991) Comparative studies of nickel, cobalt, and copper uptake by some nickel hyperaccumulators of the genus Alyssum. Plant Soil 138:196-205.

Hong C, Cutright T (2001) EDTA and HEDTA effects on Cd, $\mathrm{Cr}$, and Ni uptake by Helianthus annuus Chemosphere 45:21-28.

Jaffre T, Brooks RR, Lee J, Reeves RD (1976). Sebertia acuminata: a nickel-accumulating plant from new Caledonia. Science 193:579-580.

Jeffries P, Gianinazzi S, Perotto S, Turnau K, Barea JM (2003) The contribution of arbuscular mycorrhizal fungi in sustainable maintenance of plant health and soil fertility. Biol. Fert. Soils 37:1-16.

John P, Anderson M (1997) Trace metal bioavailability in municipal solid waste and sewage sludge composts Bioresour. Technol. 60:223-229.

Joner EJ, Leyval C (1997) Uptake of ${ }^{109} \mathrm{Cd}$ roots and hyphae of a Glomus mossae/Trifolium subterraneum mycorrhiza from soil amended with high and low concentrations of cadmium. New Phytol. 135:353-360.

Kaldorf M, Kuhn AJ, Schroder WH, Hildebrandt U, Bothe H (1999) Selective element deposits in maize colonized by a heavy metal tolerance conferring arbuscular mycorrhizal fungus. J. Plant Physiol. 154:718-728.

Kelly PC, Brooks RR, Dilli S, Jaffré T (1975) Preliminary observation on the ecology and plant chemistry of some nickel-accumulating plant from New Caledonia. Proc. R. Soc. London, Section B 189:69-80.

Kersten WJ, Brooks RR, Reeves RD, Jaffr A (1980). Nature of nickel complexes in Psychotria douarrei and other nickelaccumulating plants. Phytochemistry 19:1963-1965.

Khknen MA, Kairesalo T (1998) The effects of nickel on the nutrient fluxes and on the growth of Elodea Canadensis. Chemosphere 37:1521-1530.

Kidd PS, Llugany M, Poschenrieder C, Gunsé B, Barceló J (2001) The role of root exudates in aluminium resistance and silicon-induced amelioration of aluminium toxicity in three varieties of maize (Zea mays L.). J. Exp. Bot. 52: 1339-1352.

Kiptoo JK, Ngila JC, Sawula GM (2004) Speciation studies of nickel and chromium in wastewater from an electroplating plant. Talanta 64:54-59.

Kramer U, Cotter-Howells JD, Charnock JM, Baker AJM, Smith JAC (1996) Free histidine as a metal chelator in plants that accumulate nickel. Nature 379:635-638.

Krämer U, Grime GW, Smith JAC, Hawes CR, Baker AJM (1997) Micro-PIXE as a technique for studying nickel localization in leaves of the hyperaccumulator plant Alyssum lesbiacum. Nucl. Instr. Methods Phys. Res. B 130:346-350. 
Krämer U, Smith D, Wenzel WW, Raskin J, Salt DE (1997) The role of metal transport and tolerance in nickel hyperaccumulation by Thlaspi goesingense Halácsy. Plant Physiol. 115:1641-1650.

Kruckeberg AR, Reeves RD (1995) Nickel accumulation by serpentine species of Streptanthus (Brassicaceae): field and greenhouse studies. Madrono 42:458-469.

Kruckeberg AR, Adigzel N, Reeves RD (1999) Glimpses of the flora and ecology of Turkish (Anatolian) serpentines . Karaca Arboretum Mag. 5:67-86.

Krupa Z, Siedlecka A, Maksymiec W, Baszynski T (1993) In vivo response of photosynthetic apparatus of Phaseolus vulgaris to nickel toxicity. J. Plant Physiol. 142:664-668.

Lagerwerff JV, Specht AW (1970) Contamination of road side soil and vegetation with cadmium, nickel, lead and zinc. Environ. Sci. Technol. 4:583-586.

Lee J, Reeves RD, Brooks RR, Jaffré T (1977) Isolation and identification of a citrate complex of nickel from nickelaccumulating plants. Phytochemistry 16:1502-1505.

Lee J, Reeves RD, Brooks RR, Jaffré T (1978) The relation between nickel and citric acid in some nickel-accumulating plants. Phytochemistry 17:1033-1035.

Levin DA(1976) The chemical defenses of plants to pathogens and herbivores. Annu. Rev. Ecol. Syst. 7:121-159.

Martens SN, Boyd RS (1994) The ecological significance of nickel hyperaccumulation: a plant chemical defense. Oecologia 98:379-384.

McCutcheon SC, Schnoor JL (2003) Phytoremediation - transformation and control of contaminants. Wiley Interscience, Hoboken, USA.

McIlveen WD, Negusanti JJ (1994) Nickel in the terrestrial environment. Sci. Total Environ. 148:109-138.

Mesjasz-Przybylowicz J, Balkwill K, Przybylowicz WJ, Annegard HJ, Rama DBK (1996) Similarity of nickel distribution in leaf 189 tissue of two distantly related hyperaccumulating species. In: van der Maesen LJG, XM van der Burgt, JM van Medenbach de Rooy (eds), The biodiversity of African plants, pp 331-335. Kluwer, Dordrecht, The Netherlands.

Mesjasz-Przybylowicz J, Balkwill K, Przybylowicz WJ, Annegarn HJ (1994) Proton microprobe and X-ray fluorescence investigation of nickel distribution in serpentine flora from South Africa. Nucl. Instr. Meth. Phys. Res. B 89: 208-212.

Mesjasz-Przybylowicz J, Przybylowicz W, Ostachowicz B, Augustyniak M, Nakonieczny M, Migula P (2002) Trace elements in the chrysomelid beetle (Chrysolina pardalina) and its Ni-hyperaccumulating host-plant (Berkheya coddii). Fresen Environ. Bull. 11:78-84.

Mesjasz-Przybylowicz J, Przybylowicz WJ, Rama DBK, Pineda CA (2001a) Elemental distribution in Senecio anomalochrous, a Ni hyperaccumulator from South Africa. S. Afr. J. Sci. 97:593-595.

Mesjasz-Przybylowicz J, Przybylowicz WJ, Pineda CA (2001b) Nuclear microprobe studies of elemental distribution in apical leaves of the Ni hyperaccumulator Berkhya coddii. S. Afr. J. Sci. 97:591-593.
Mishra D, Kar M (1974) Nickel in plant growth and metabolism. Bot. Rev. 40:395-452.

Mohanty N, Vass I, Demeter S (1989) Impairment of photosystem II activity at the level of secondary quinone electron-acceptor in chloroplasts treated with cobalt, nickel and zinc ions. Physiol. Plant. 76:386-390.

Molas J, Baran S (2004) Relationship between the chemical form of nickel applied to the soil and its uptake and toxicity to barley plants (Hordeum vulgare L.) Geoderma 122: 247-255.

Monni S, Salemaa M, Millar N (2000) The tolerance of Empetrum nigrum to copper and nickel. Environ. Pollut. 109: 221-229.

Morrey DR, Balkwill K, Balkwill MJ (1989) Studies on serpentine flora: Preliminary analyses of soils and vegetation associated with serpentinite rock formations in the southeastern Transvaal. S. Afr. J. Bot. 55:171-177.

Morrison RS, Brooks RR, Reeves RD (1980) Nickel uptake by Alyssum species. Plant Sci. Lett. 17:453-457.

Moskalyk RR, Alfantazi AM (2002) Nickel laterite processing and electrowinning practice. Miner. Engin. 15:593-605.

Moya JL, Ros R, Picazo I (1993) Influence of cadmium and nickel on growth, net photosynthesis and carbohydrate distribution in rice plants. Photosynth. Res. 6:75-80.

Munch D (1993) Concentration profiles of arsenic, cadmium, chromium,copper, lead, mercury, nickel, zinc, vanadium and polynuclear aromatic hydrocarbons $(\mathrm{PAH})$ in forest soil beside an urban road. Sci. Tot. Environ. 138:47-55.

Murch SJ, Haq K, Rupasinghe HPV, Saxena PK (2003) Nickel contamination affects growth and secondary metabolite composition of St. John's wort (Hypericum perforatum L.) Environ. Exp. Bot. 49:251-257.

Neumann PM, Chamel A (1986) Comparative phloem mobility of nickel in nonsenescent plants. Plant Physiol. 81: 689-691.

Nicks L, Chambers MF (1998) A pioneering study of the potential of phytomining for nickel. In: Brooks RR (ed), Plants that hyperaccumulate heavy metals, pp.313-326. CAB, Wallingford, UK.

Nicolaidou JA, Nott A (1989) Heavy metal pollution induced by a ferro-nickel smelting plant in Greece. Sci. Total Environ. 84:113-117.

Oller AR, Costa M, Oberdorster G (1997) Carcinogenicity assessment of selected nickel compounds. Toxicol. Appl. Pharmacol. 143:152-166.

Outridge PM, Sheuhammer AM (1993) Bioaccumulation and toxicology of nickel: implications for wild mammals and birds. Environ. Rev. 1:172-197.

Oxelfelt F, Tamagnini P, Salema R, Lindblad P (1995) Hydrogen uptake in Nostoc strain PCC 73102: Effects of nickel, hydrogen, carbon and nitrogen. Plant Physiol. Biochem. 33:617-623.

Parida BK, Chhibba IM, Nayyar VK (2003) Influence of nickel-contaminated soils on fenugreek (Trigonella corniculata L.) growth and mineral composition . Sci. Hortic. 98:113-119.

Pearsans MW, Yan X, Patnoc JMML, Krämer U, Salt DE (1999) Molecular dissection of the role of histidine in nick- 
el hyperaccumulation in Thlaspi goesingense (Halácsy). Plant Physiol. 121:1117-1126.

Pelosi P, Fiorentini R, Galoppini C (1976) On the nature of nickel compounds in Alyssum bertolonii Desv. Agr. Biol. Chem. 40:1641-1642.

Peralta-Videa JR, Gardea-Torresdey JL, Gomez E, Tiemann KJ, Parsons JG, Carrillo G (2002) Effect of mixed cadmium, copper, nickel and zinc at different pHs upon alfalfa growth and heavy metal uptake. Environ. Pollut. 119: 291-301.

Perrier N, Colin F, Jaffr T, Ambrosi J-P, Rose J, Bottero JY (2004) Nickel speciation in Sebertia acuminata, a plant growing on a lateritic soil of New Caledonia. Comp. R. Geosci. 336:567-577.

Peterka J, Kužel S, Illéš L, Moudrý J (2001) Determining the content of elements in Amaranth (Amaranthus L.). ISEB Phytoremediation, UFZ Ctr Envir. Leipzig. p. 91.

Peterson LR, Trivett V, Baker AJM, Aguiar C, Pollard PJ (2003) Spread of metals through an invertebrate food chain as influenced by a plant that hyperaccumulates nickel. Chemoecology 13:103-108.

Plenchette C, Fortin JA, Furlan V (1983) Growth response of several plant species to mycorrhizae in a soil of moderate P fertility. I. Mycorrhizal dependency under field conditions. Plant Soil 70:199-209.

Pnnazio S, Roggero P (1992) Effect of cadmium and nickel on ethylene biosynthesis in soybean. Biol. Plant. 34: 345-349.

Polacco JC (1977) Is nickel a universal component of plant ureases? Plant Sci. Lett. 10:249-255.

Pollard AJ (2000) Metal hyperaccumulation: a model system for coevolutionary studies. New Phytol. 146:179-181.

Pollard AJ, Baker AJM (1997) Deterrence of herbivory by zinc hyperaccumulation in Thlaspi caerulescens (Brassicaceae). New Phytol. 135:655-658.

Pollard AJ, Dandridge KL, Jhee EM (2000) Ecological genetics and the evolution of trace element hyperaccumulation in plants. In: Terry N, Bañuelos GS (eds), Phytoremediation of contaminated soil and water, pp.251-264. CRC Press, Boca-Raton.

Prasad MNV (2001) Metals in the environment - analysis by biodiversity. Marcel Dekker Inc. New York.

Prasad MNV (2003) Phytoremediation of metal-polluted ecosystems: Hype for commercialization. Russ. J. Plant Physiol. 50:686-701.

Prasad MNV (2004) Phytoremediation of metals and radionuclides in the environment: The case for natural hyperaccumulators, metal transporters, soil amending chelators and transgenic plants, In: M N V Prasad (ed), Heavy Metal Stress in plants: From biomolecules to Ecosystems, $2^{\text {nd }}$ edn, pp.345-391. Springer-Verlag. Heidelberg. Narosa New Delhi.

Prasad MNV (2004) Phytoremediation of metals in the environment for sustainable development. Proc. Indian Natl. Sci. Acad. 70:71-98.

Prasad MNV, Freitas H (1999) Feasible biotechnological and bioremediation strategies for serpentine soils and mine spoils. Electronic J. Biotechnol. 2:36-50. Online journal, Available from Internet: http://www.ejbiotechnology.info / content/vol2/ issue1/full/5/index.html.

Prasad MNV, Freitas H (2003) Metal hyperaccumulation in plants - Biodiversity prospecting for phytoremediation technology. Electronic J. Biotechnol. 6:275-321. Online electronic journal http://www. ejbiotechnology. info/ content/vol6/issue3/index.html.

Prasad MNV, Strzalka K (2002) Physiology and biochemistry of metal toxicity and tolerance in plants. Kluwer Academic Publishers. Dordrecht.

Proctor J, Woodell SRJ (1975) The ecology of serpentine soils. Adv. Ecol. Res. 9:256-347.

Rai LC, Raizada M (1986) Nickel-induced stimulation of growth, heterocyst differentiation, ${ }^{14} \mathrm{CO} 2$ uptake and nitrogenase activity in Nostoc muscorum. New Phytol. 104: 111-114.

Rao MV, Dubey PS (1992) Occurrence of heavy metals in air and their accumulation by tropical plants growing around an industrial area. Sci. Total Environ. 126:1-16.

Rauser WE, Dumbroff EB (1981) Effects of excess cobalt, nickel and zinc on the water relations of Phaseolus vulgaris. Environ. Exp. Bot. 21:249-255.

Reddy MR, Dunn SJ (1984) Accumulation of heavy metals by soybean from sludge-amended soil. Environ. Pollut. Series B, Chemical and Physical 7:281-295.

Reeves RD (1988) Nickel and zinc accumulation by species of Thlaspi L., Cochlearia L., and other genera of Brassicaceae. Taxon 37:309-318.

Reeves RD (1992) The accumulation of nickel by serpentine plants. In: Baker AJM, Proctor J, Reeves RD (eds), The Vegetation of Ultramafic (serpentine) Soils. Proceedings of the First International Conference on Serpentine Ecology, University of California, Davis, 1991. Andove: Intercept Ltd, pp 253- 277.

Reeves RD, Brooks RR (1983) European species of Thlaspi L. (Cruciferae) as indicators of nickel and zinc. J. Geochem. Expl. 18:275-283.

Reeves RD, Baker AJM, Borhidi A, Berazain R (1996) Nickel accumulating plants from the ancient serpentine soils of Cuba. New Phytol. 133:217-224.

Reeves RD, Baker AJM (2000) Metal-accumulating plants. In: Raskin I, Ensley BD (eds) Phytoremediation of toxic metals: using plants to clean up the environment, pp.193229. John Wiley \& Sons, New York.

Reeves RD, Baker AJM, Borhidi A, Berazain R (1999) Nickel hyperaccumulation in the serpentine flora of Cuba. Ann. Bot. 83:29-38.

Reeves RD, Brooks RR, Macfarlane RM (1981) Nickel uptake by Californian Streptanthus and Caulanthus with particular reference to the hyperaccumulator, S. polygaloides Gray (Brassicaceae) Am. J. Bot. 68:708-712.

Reeves RD, Brooks RR (1983) European species of Thlaspi L. (Cruciferae) as indicators of nickel and zinc. J. Geochem. Explor. 18:275-283.

Reeves RD, Macfarlane R, Brooks RR (1983) Accumulation of nickel and zinc by western North American gen- 
era containing serpentine-tolerant species. Am. J. Bot. 70: 1297-1303.

Reeves RD, Brooks RR, Dudley TR(1983) Uptake of nickel by species of Alyssum bornmuellera and other genera of Old World Tribus Alyssae. Taxon 32:184-192.

Reimann C, Koller F, Kashulina G, Niskavaara H, Englmaier $P$ (2001) Influence of extreme pollution on the inorganic chemical composition of some plants. Environ. Pollut. 115:239-252.

Rengaraj S, Yeon K-H, Kang S-Y, Lee J-U, Kim K-W, Moon S-H (2002) Studies on adsorptive removal of Co(II), Cr(III) and Ni(II) by IRN77 cation-exchange resin. J. Hazardous Mat. 92:185-198.

Robinson BH, Brooks RR, Clothier BE (1999) Soil amendments affecting nickel and cobalt uptake by Berkheya coddii: potential use for phytomining and phytoremediation Ann. Bot. 84:689-694.

Robinson BH, Brooks RR, Howes AW, Kirkman JH, Gregg PEH (1997) The potential of the high-biomass nickel hyperaccumulator Berkheya coddii for phytoremediation and phytomining J. Geochem. Expl. 60:115-126.

Robinson BH,Chiarucci A, Brooks RR, Petit D, Kirkman JH, Gregg PEH, De Dominicis V (1997) The nickel hyperaccumulator plant Alyssum bertolonii as a potential agent for phytoremediation and phytomining of nickel. J. Geochem. Expl. 59:75-86.

Roels H, Voorde R, Vargas VMM, Lauwerys R (1993) Relationship between atmospheric and urinary nickel in workers manufacturing electrical resistances using nickel oxide: role of the bioavailability of nickel. J. Environ. Occup. Med. 43:95-104.

Ros R, Cooke DT, Burden RS and James CS (1990) Effect of the herbicide MCPA, and the heavy metals, cadmium and nickel on the lipid composition, Mg-ATPase activity and fluidity of plasma membranes from rice, Oryza sativa cv. Bahia shoots. J. Exp. Bot. 41:457-462.

Ros R, Morales A, Segura J, Picazo I (1992) In vivo and in vitro effects of nickel and cadmium on the plasmalemma ATPase from rice (Oryza sativa L.) shoots and roots. Plant Sci. 83:1-6.

Rout GR, Samantaray S, Das P (2000) Effects of chromium and nickel on germination and growth in tolerant and non-tolerant populations of Echinochloa colona (L.) Link. Chemosphere 40:855-859.

Rubio MI, Escrig I, Martinezcortina C, Lopezbenet FJ, Sanz A (1994) Cadmium and nickel accumulation in rice plants- effects on mineral nutrition and possible interactions of abscisic and gibberellic acids. Plant Growth Regul. 14:151-157.

Ruth-Balaganskaya E, Kudrjavtseva O (2002) Sulphur migration in the soil-plant system contaminated by deposits from nickel industry: a field manipulation. Environ. Pollut. 117:287-293.

Sagner S, Kneer R, Wanner G, Cosson J-P, Deus-Neumann B, Zenk MH (1998) Hyperaccumulation, complexation and distribution of nickel in Sebertia acuminata Phytochemistry 47:339-347.

Salt DE, Baker AJM (2001) Phytoremediation of metals. In: Rehm HJ, Reed G (eds), Biotechnology, vol. 11b: Envi- ronmental Processes II, Soil Decontamination, pp.386397. Wiley VCH, New York.

Salt DE, Kato N, Krämer U, Smith RD, Raskin I (2000) The role of root exudates in nickel hyperaccumulation and tolerance in accumulator and non accumulator species of Thlaspi. In: Terry N, Bañuelos GS (eds), Phytoremediation of Contaminated Soil and Water, pp.189-200. CRC Press Inc, Boca Raton.

Salt DE, Kramer U (2000) Mechanisms of metal hyperaccumulation in plants. In: Raskin I, Ensley BD (eds), Phytoremediation of toxic metals: using plants to clean up the environment, pp.231-245.John Wiley \& Sons, New York.

Salt DE, Prince RC, Pickering IJ (2002) Chemical speciation of accumulated metals in plants: evidence from X-ray absorption spectroscopy. Microchem. J. 71:255-259.

Salt DE, Smith RD, Raskin I (1998) Phytoremediation. Annu. Rev. Plant Physiol. 49:643-668.

Samarakoon AB, Rauser WE (1979) Carbohydrate levels and photo assimilate export from leaves of Phaseolus vulgaris to excess cobalt, nickel and zinc. Plant Physiol. 63:1165-1169.

Sander ML, Ericsson T (1998) Vertical distributions of plant nutrients and heavy metals in Salix viminalis stems and their implications for sampling. Biomass Bioenergy 14:57-66.

Sanders JR, McGrath SP, Adams T (1987) Zinc, copper and nickel concentrations in soil extracts and crops grown on four soils treated with metalloaded sewage sludges. Environ. Pollut. 44:193-210.

Sandstrom J (1994) Performance of pea aphid (Acyrthosiphon pisum) clones on host plants and synthetic diets mimicking the same plants phloem amino acid composition. J. Insect Physiol. 40:1051-1057.

Sandstrom J, Pettersson J (1994) Amino acid composition of phloem sap and the relation to intraspecific variation in pea aphid (Acyrthosiphon pisum) performance. J. Insect Physiol. 40:947-955.

Sequeira EMD, Pinto da Silva AR (1991) The ecology of serpentinised areas of Northeast Portugal. In: Roberts BA and Proctor J (eds), The ecology of areas with serpentinised rocks. A world review, pp.169-197, Kluwer Academic Publishers, Dordrecht.

Schmidt T, Schlegel HG (1989) Nickel and cobalt resistance of various bacteria isolated from soil and highly polluted domestic and industrial wastes. FEMS Microbiol. Lett. 62:315-328.

Scholes L, Shutes RBE, Revitt DM, Forshaw M, Purchase D (1998) The treatment of metals in urban runoff by constructed wetlands. Sci. Total Environ. 214:211-219.

Schwitzguébel JP, van der Lelie D, Baker A, Glass DJ, Vangronsveld J (2002) Phytoremedia-tion: European and American trends. J. Soils Sediments 2:91-99.

Severne BC, Brooks RR (1972) A nickel-accumulating plant from Western Australia. Planta 103:91-94.

Shallari S,Schwartz C, Hasko A, Morel JL (1998) Heavy metals in soils and plants of serpentine and industrial sites of Albania. Sci. Total Environ. 209:133-142.

Shoeran IS, Singal HR, Singh R (1990) Effect of Cadmium and nickel on photosynthesis and the enzymes of the pho- 
tosynthetic carbon reduction cycle in Pigeon pea (Cajanus cajan). Photosynthesis Research. 23:345-351.

Simpson SJ, Abisgold JD, Douglas AE (1995) Response of the pea aphid (Acyrthosiphon pisum) to variation in dietary levels of sugar and amino acids: the significance of amino acid quality. J Insect Physiol 41:71-75.

Singh R, Ellis PR, Pink DAC, Phelps K (1994) An investigation of the resistance to cabbage aphid in brassica species. Ann. Appl. Biol. 125:457-465.

Singh RN, Keefer RF (1989) Uptake of nickel and cadmium by vegetables grown on soil amended with different sewage sludges. Agric. Ecosys. Environ. 25:27-38.

Siqueira MEPB, Oliveira JP (1998) Urinary nickel as bioindicator of Ni exposure of workers in a galvanizing plant in Brazil. Toxicol. Lett. 95:137.

Smith SE, Read DJ (1997) The Mycorrhizal Symbiosis, $2^{\text {nd }}$ edn. Academic Press, London.

Smith CJ (1996) Accumulation of phytoalexins: defence mechanism and stimulus response system. New. Phytol. 132:1-45.

Snow A, Stanton M (1988) Aphids limit fecundity of a weedy annual (Raphanus sativus). Am. J. Bot. 75:589-593.

Soczynska-Kordala M, Bakowska A, Oszmianski J, Gabrielska J (2001) Cell. Molec. Biol. Lett. 6:277-281.

Srivastava SK, Tyagi R, Nalini (1989) Plant adsorption of heavy metal ions on carbonaceous material developed from the waste slurry generated in local fertilizer plants. Water Res. 23:1161-1165.

Stamboliadis E, Alevizos G, Zafiratos J (2004) Leaching residue of nickeliferous laterites as a source of iron concentrate. Min. Engineer. 17:245-252.

Taylor GJ, Stadt KJ, Dale MR (1991) Modelling the phytotoxicity of aluminum, cadmium, copper, manganese, nickel, and zinc using the Weibull frequency distribution. Can. J. Bot. 69:359-367.

Turnau K, Mesjasz-Przybylowicz J (2003) Arbuscular mycorrhiza of Berkheya coddii and other Ni-hyperaccumulating members of Asteraceae from ultramafic soils in South Africa. Mycorrhiza 13:185-190.

Tyler G (2004) Ionic charge, radius, and potential control root/ soil concentration ratios of fifty cationic elements in the organic horizon of a beech (Fagus sylvatica) forest podzol. Sci. Total Environ. 329:231-239.

Uhlig C and Junttila O (2001) Airborne heavy metal pollution and its effects on foliar elemental composition of Empetrum hermaphroditum and Vaccinium myrtillus in S r-Varanger, northern Norway. Environ. Pollut. 114:461-469.

Uhlig C, Salemaa M, Vanha-Majamaa I, Derome J (2001) Element distribution in Empetrum nigrum microsites at heavy metal contaminated sites in Harjavalta, western Finland. Environ. Pollut. 112:435-442.

US Dept of Energy (1994) Summary report of a workshop on phytoremediation research needs. DOE/EM-0224. USA, VA-Springfield: National Technical Information Service. van Straalen NM, Ernst WHO (1991) Metal biomagnification may endanger species in critical pathways. Oikos 62:255-256.
Vangronsveld J, Cunningham SD (1998) Metal-contaminated soils: in-situ inactivation and phytorestoration. SpringerVerlag, Berlin, Heidelberg.

Varennes A, de Torres MO, Coutinho JF, Rocha MMGS, Neto MMPM, De-Varennes A (1996) Effects of heavy metals on the growth and mineral composition of a nickel hyperaccumulator. J. Plant Nutr. 19:669-676.

Vazquez MD, Barcelo J, Poschenreider CH, Madico J, Hatton P, Baker AJM, Cope GH (1992) Localization of zinc and cadmium in Thlaspi caerulescens (Brassicaceae), a metallophyte that can hyperaccumulate both metals. J. Plant Physiol. 140:350-355.

Vergnano O (1967) Primi dati sulla localizzazione del nichel in Alyssum bertolonii Desv. Giorn. Bot. Ital. 101:59-60.

Vergnano O, Pancaro L, Formica C (1977) Investigation on a nickel-accumulating plant Alyssum bertolonii Desv. I nickel, calcium and magnesium content and distribution during growth. Webbia 32:175-188.

Vergnano O, Gabbrielli R (1979) Ecophysiological and geochemical aspects of nickel, chromium and cobalt accumulation in the vegetation of some Italian ophiolitic outcrops. Ofioliti 4:199-208.

Vicente S, Maniasso N, Queiroz ZF, Zagatto EAG (2002) Spectro-photometric flow-injection determination of nickel in biological materials. Talanta 57:475-480.

Vincent L, Sauvage T, Lacroix O, Saillard M, Blondiaux G, Guinard L (2002) Simplified methodology of the ultra-thin layer activation technique. Nucl. Instr. Methods Phys. Res., Section B: Beam Interac. Mat. Atoms 190:831-834.

Vivanco JM, Guimaräes RL, Flores HE (2002) Underground plant metabolism: the biosynthetic potential of roots. In: Waisel Y, Eshel A, Kafkafi U (eds), Plant Roots. The Hidden Half, pp.1045-1070. Marcel Dekker, Inc., New York.

Walker C, Vestberg M (1994) A simple and inexpensive method for producing and maintaining closed pot cultures of arbuscular mycorrhizal fungi. Agric. Sci. Finland 3:233-240.

Walker TS, Bais HP, Grotewold E, Vivanco JM (2003) Root exudation and rhizosphere biology. Plant Physiol. 132:44-51.

Wall MA, Boyd RS (2002) Nickel accumulation in serpentine arthropods from the Red Hills, California. Pan-Pac Entomol. 78:168-176.

Warcup JH (1990) The mycorrhizal association of some Australian Inuleae. Muelleria 7:179-187.

Warcup JH, McGee PA (1983) The mycorrhizal association of some Australian Asteraceae. New Phytol. 95:667-672.

Watt RK, Ludden PW (1999) Nickel-binding proteins. Cell. Mol. Life Sci. 56:604-625.

Wither ED, Brooks RR (1977) Hyperaccumulation of nickel by some plants of Southeast Asia. J. Geochem. Explor. 8:579-583.

Youngs WD, Rutzke M, Gutenmann WH, Lisk DJ (1993) Nickel and vanadium in foliage in the vicinity of an oil-fired power plant. Chemosphere 27:1269-1272.

Zdenek P (1997) The danger of cumulation of nickel in cereals on contaminated soil. Agric. Ecosys. Environ. 63:25-29.

Zeller S, Feller U (1999) Long-distance transport of cobalt and nickel in maturing wheat. Eur. J. Agron. 10:91-98. 